Prepared in cooperation with the U.S. Environmental Protection Agency

\title{
Total Mercury, Methylmercury, and Selected Elements in Soils of the Fishing Brook Watershed, Hamilton County, New York, and the McTier Creek Watershed, Aiken County, South Carolina, 2008
}

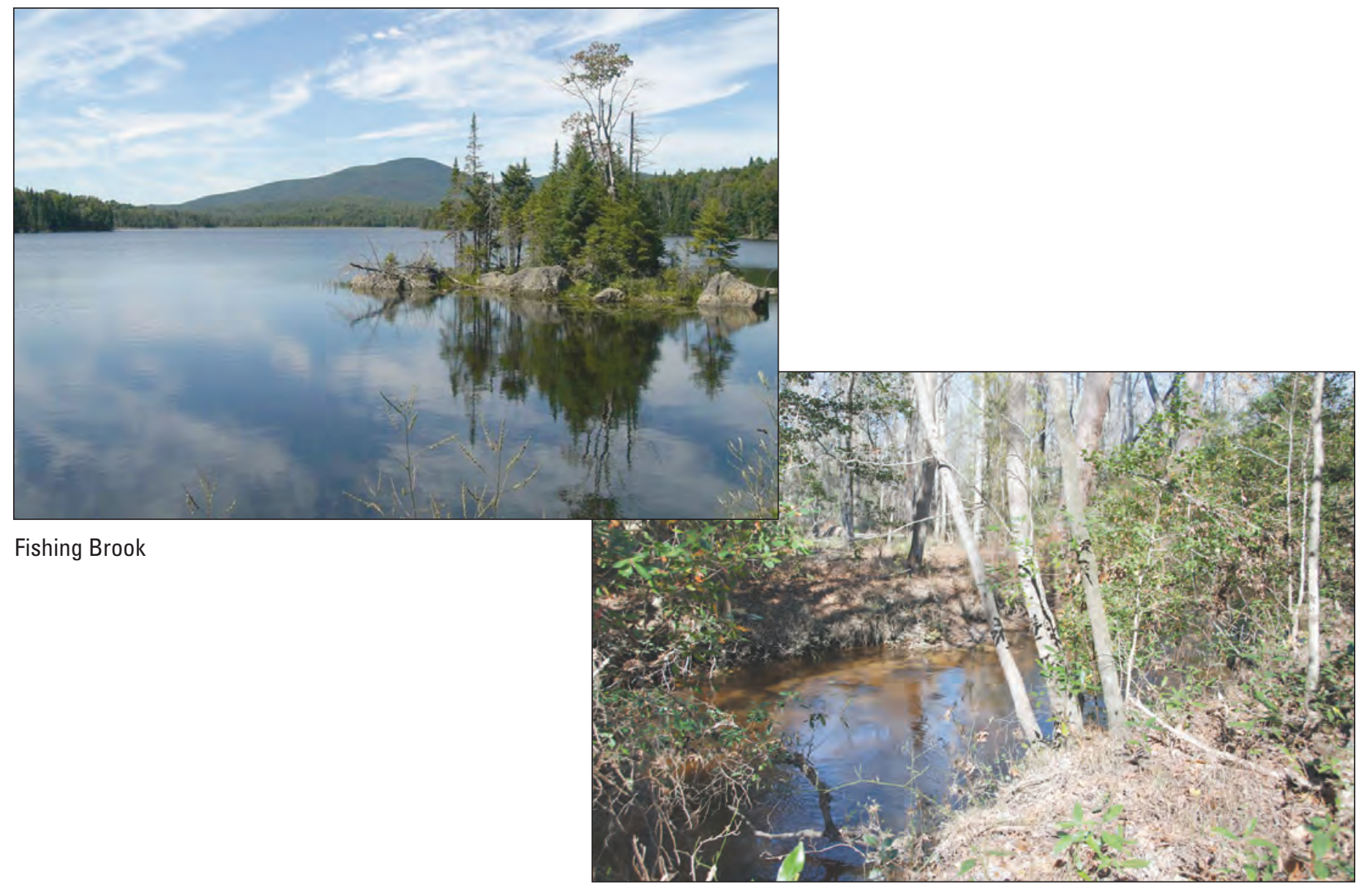

Data Series 516

$$
\text { McTier Creek }
$$


Cover. Left: County line flow, Hamilton County, New York. Photo by Douglas A. Burns, USGS. Right: McTier Creek, Aiken County, South Carolina. Photo by Paul M. Bradley, USGS. 


\section{Total Mercury, Methylmercury, and Selected Elements in Soils of the Fishing Brook Watershed, Hamilton County, New York, and the McTier Creek Watershed, Aiken County, South Carolina, 2008}

By Laurel G. Woodruff, William F. Cannon, Christopher D. Knightes, Francis H. Chapelle, Paul M. Bradley, Douglas A. Burns, Mark E. Brigham, and Mark A. Lowery

Prepared in cooperation with the U.S. Environmental Protection Agency

Data Series 516 


\section{U.S. Department of the Interior \\ KEN SALAZAR, Secretary \\ U.S. Geological Survey \\ Marcia K. McNutt, Director}

\section{U.S. Geological Survey, Reston, Virginia: 2010}

For more information on the USGS - the Federal source for science about the Earth, its natural and living resources, natural hazards, and the environment, visit http://Www.usgs.gov or call 1-888-ASK-USGS

For an overview of USGS information products, including maps, imagery, and publications, visit $h$ ttp://www.usgs.gov/pubprod

To order this and other USGS information products, visit http://store.usgs.gov

Any use of trade, product, or firm names is for descriptive purposes only and does not imply endorsement by the U.S. Government.

Although this report is in the public domain, permission must be secured from the individual copyright owners to reproduce any copyrighted materials contained within this report.

Suggested citation:

Woodruff, L.G., Cannon, W.F., Knightes, C.D., Chapelle, F.H., Bradley, P.M., Burns, D.A., Brigham, M.E., and Lowery, M.A., 2010, Total mercury, methylmercury, and selected elements in soils of the Fishing Brook watershed, Hamilton County, New York, and the McTier Creek watershed, Aiken County, South Carolina, 2008: U.S. Geological Survey Data Series 516, 10 p. 


\section{Contents}

Abstract
Introduction.
Methods of Investigation
$\quad$ Soil Sampling
$\quad$ Soil-Sample Analyses
Total Mercury, Methylmercury, and Selected Elements in Soils
References Cited

\section{Figures}

1-4. Maps showing-

1. Land cover for Fishing Brook watershed in New York, 2001 ....................................2

2. Land cover for McTier Creek watershed in South Carolina, 2001 ............................3

3. Soil-sample locations in the Fishing Brook watershed, New York, 2008...................5

4. Soil-sample locations in the McTier Creek watershed, South Carolina, 2008 ..........6

5. Diagram showing soil horizons sampled in the Fishing Brook watershed, New York, and the McTier Creek watershed, South Carolina, 2008..................................7

\section{Tables}

1. Characteristics of Fishing Brook and McTier Creek watersheds.......................................

2. Analytes, reporting limits, and analytical methods used for soil samples........................9

3. Geochemical analyses for soil samples collected in the Fishing Brook watershed, New York, 2008 .................................... download separate file

4. Geochemical analyses for soil samples collected in the McTier Creek watershed, South Carolina, 2008. download separate file

Tables 3 and 4 are available at $h t t p: / / p u b s . u s g s . g o v / d s / 516 /$ 


\section{Conversion Factors and Datums}

\begin{tabular}{lcl}
\hline \multicolumn{1}{c}{ Multiply } & By & \multicolumn{1}{c}{ To obtain } \\
\hline & Length & \\
\hline centimeter $(\mathrm{cm})$ & 0.3937 & inch \\
millimeter $(\mathrm{mm})$ & 0.03937 & inch \\
\hline & Area & \\
\hline square mile $\left(\mathrm{mi}^{2}\right)$ & 259.0 & hectare (ha) \\
square mile $\left(\mathrm{mi}^{2}\right)$ & 2.590 & square kilometer $\left(\mathrm{km}^{2}\right)$ \\
\hline & Volume & \\
\hline cubic centimeter $\left(\mathrm{cm}^{3}\right)$ & 0.06102 & cubic inch (in $\left.{ }^{3}\right)$ \\
\hline & Mass & \\
\hline gram $(\mathrm{g})$ & 0.03527 & ounce, avoirdupois $(\mathrm{oz})$ \\
\hline
\end{tabular}

Temperature in degrees Celsius $\left({ }^{\circ} \mathrm{C}\right)$ may be converted to degrees Fahrenheit $\left({ }^{\circ} \mathrm{F}\right)$ as follows:

$$
{ }^{\circ} \mathrm{F}=\left(1.8 \times{ }^{\circ} \mathrm{C}\right)+32
$$

Temperature in degrees Fahrenheit $\left({ }^{\circ} \mathrm{F}\right)$ may be converted to degrees Celsius $\left({ }^{\circ} \mathrm{C}\right)$ as follows:

$$
{ }^{\circ} \mathrm{C}=\left({ }^{\circ} \mathrm{F}-32\right) / 1.8
$$

Horizontal coordinate information is referenced to the World Geodetic Datum of 1984 (WGS 84) or the North American Datum of 1983 (NAD 83).

Concentrations of chemical constituents in soil are given in parts per million (ppm) or percent by weight (wt \%).

NOTE TO USGS USERS: Use of hectare (ha) as an alternative name for square hectometer $\left(\mathrm{hm}^{2}\right)$ is restricted to the measurement of small land or water areas. Use of liter (L) as a special name for cubic decimeter $\left(\mathrm{dm}^{3}\right)$ is restricted to the measurement of liquids and gases. No prefix other than milli should be used with liter. Metric ton (t) as a name for megagram (Mg) should be restricted to commercial usage, and no prefixes should be used with it. 


\title{
Total Mercury, Methylmercury, and Selected Elements in Soils of the Fishing Brook Watershed, Hamilton County, New York, and the McTier Creek Watershed, Aiken County, South Carolina, 2008
}

\author{
By Laurel G. Woodruff, William F. Cannon, Christopher D. Knightes, ${ }^{1}$ Francis H. Chapelle, \\ Paul M. Bradley, Douglas A. Burns, Mark E. Brigham, and Mark A. Lowery
}

Abstract

Mercury is an element of on-going concern for human and aquatic health. Mercury sequestered in upland and wetland soils represents a source that may contribute to mercury contamination in sensitive ecosystems. An improved understanding of mercury cycling in stream ecosystems requires identification and quantification of mercury speciation and transport dynamics in upland and wetland soils within a watershed. This report presents data for soils collected in 2008 from two small watersheds in New York and South Carolina. In New York, 163 samples were taken from multiple depths or soil horizons at 70 separate locations near Fishing Brook, located in Hamilton County. At McTier Creek, in Aiken County, South Carolina, 81 samples from various soil horizons or soil depths were collected from 24 locations. Sample locations within each watershed were selected to characterize soil geochemistry in distinct land-cover compartments. Soils were analyzed for total mercury, selenium, total and carbonate carbon, and 42 other elements. A subset of the samples was also analyzed for methylmercury.

\section{Introduction}

Mercury contamination of aquatic food webs is at least partly to blame for 80 percent of all fish-consumption advisories issued in the United States (U.S. Environmental Protection Agency, 2009), and mercury is the second-leading cause of Section 303(d) Total Maximum Daily Load (TMDL) impairments of U.S. water bodies (U.S. Environmental

${ }^{1}$ U.S. Environmental Protection Agency, Office of Research and Development, National Exposure Research Laboratory, Ecosystems Research Division, Athens, GA 30605.
Protection Agency, 2010). The total mercury found in most watersheds originates from regional and global sources whose emissions are transported and deposited atmospherically. Because the terrestrial area of a watershed is typically much larger than the aquatic area, the soils within these watersheds tend to hold the largest "pools" of atmospherically deposited mercury and are likely the most significant immediate contributor of mercury to surface waters (Grigal, 2002). Wetland soils in particular play a critical role as both a source and sink for mercury and methylmercury in watersheds (Krabbenhoft and others, 2005). The purpose of this report is to document basic data on the elemental composition, including mercury and methylmercury, of soils that underlie two geographically and geologically distinct watersheds in the Eastern United States.

Soils retain much of the mercury that arrives from the atmosphere; thus, they provide a long-term source that can deliver mercury to surface waters via runoff of mercury bound to particulates, colloids, and, in dissolved form, associated with various organic and inorganic ligands. The terrestrial component of a watershed may contribute as much as 70 percent of the atmospherically derived mercury that reaches a lake or stream (Krabbenhoft and Babiarz, 1992; Lorey and Driscoll, 1999; Grigal, 2002; Krabbenhoft and others, 2005). An improved understanding of mercury cycling in stream ecosystems requires identification and quantification of its speciation and transport dynamics in terrestrial and wetland soils within a watershed.

The U.S. Geological Survey (USGS) National WaterQuality Assessment (NAWQA) Program is conducting detailed investigations of mercury cycling and bioaccumulation in stream ecosystems as part of a national mercury study. A major objective of the NAWQA studies is to determine the influence of landscape characteristics, such as the percentage of wetlands in a watershed, on the transformation of inorganic mercury to methylmercury and its uptake into the aquatic food webs of stream ecosystems across the Nation. 
Current NAWQA mercury studies began in 2006. These studies examine spatial dynamics of mercury and methylmercury in stream ecosystems, as well as seasonal and interannual variations of the mercury cycle. As part of the secondphase of NAWQA studies, 1 year of data was collected in the upper Hudson River Basin, New York, and the Edisto River Basin, South Carolina. Data collection included time-series monitoring (approximately monthly) of the water column at the basin outlets and synoptic sampling (1-2 samples per site) of selected tributaries.

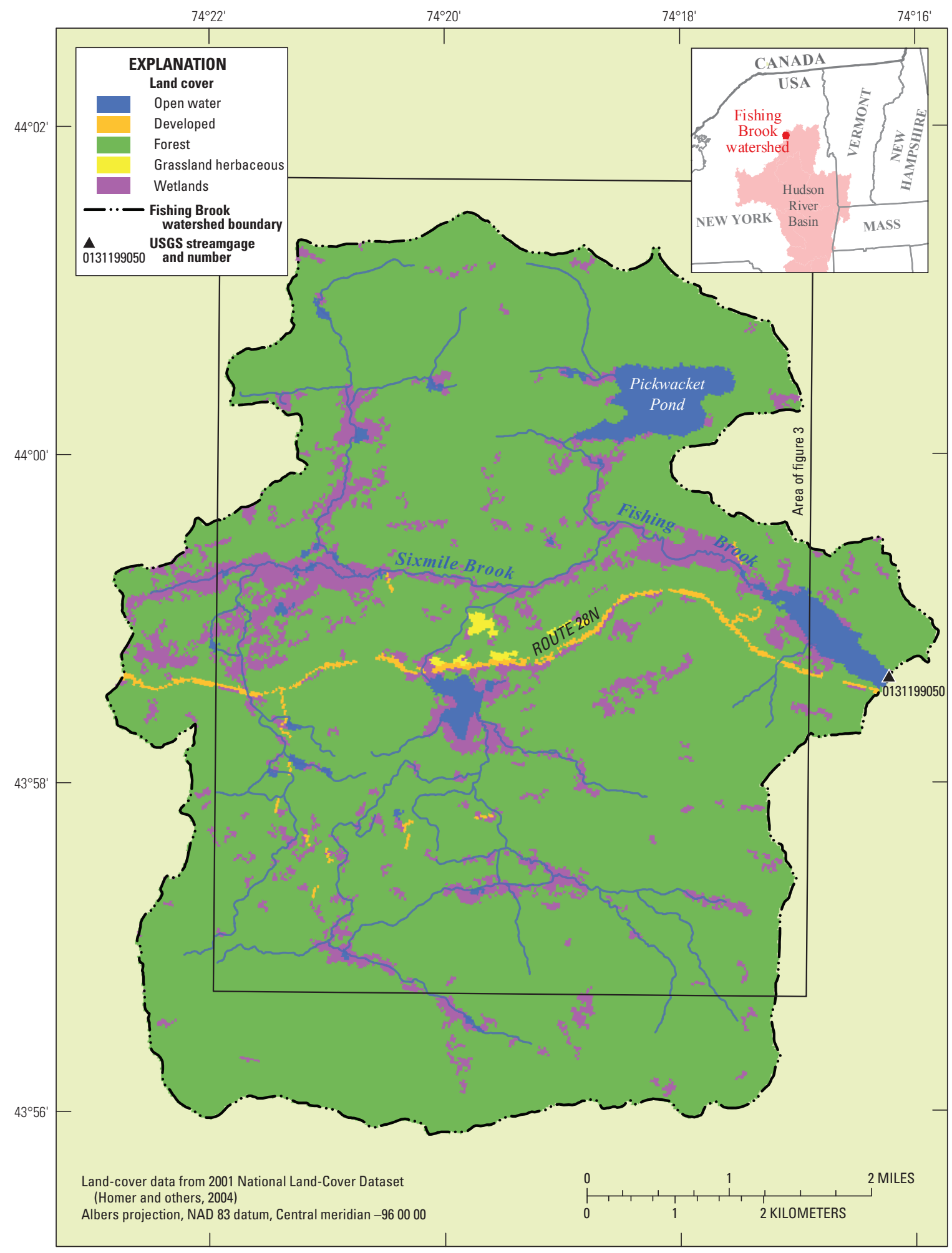

Figure 1. Land-cover map for Fishing Brook watershed in New York, 2001. 
In October 2006, studies were re-scoped to focus on small watersheds within the larger river basins. The New York study area is the Fishing Brook watershed upstream of USGS streamgage 0131199050 (fig. 1). The South Carolina study area is the McTier Creek watershed upstream of USGS streamgage 02172305 (fig. 2). Both watersheds are similar in size (25-30 square miles), have minimal development (less than 6 percent), and are within actively managed forests (prescribed burning, logging). Riparian wetlands in proximity to stream channels abound in each watershed. Geospatial data analysis and multiple reconnaissance visits have revealed several other similarities between the two watersheds (table 1).

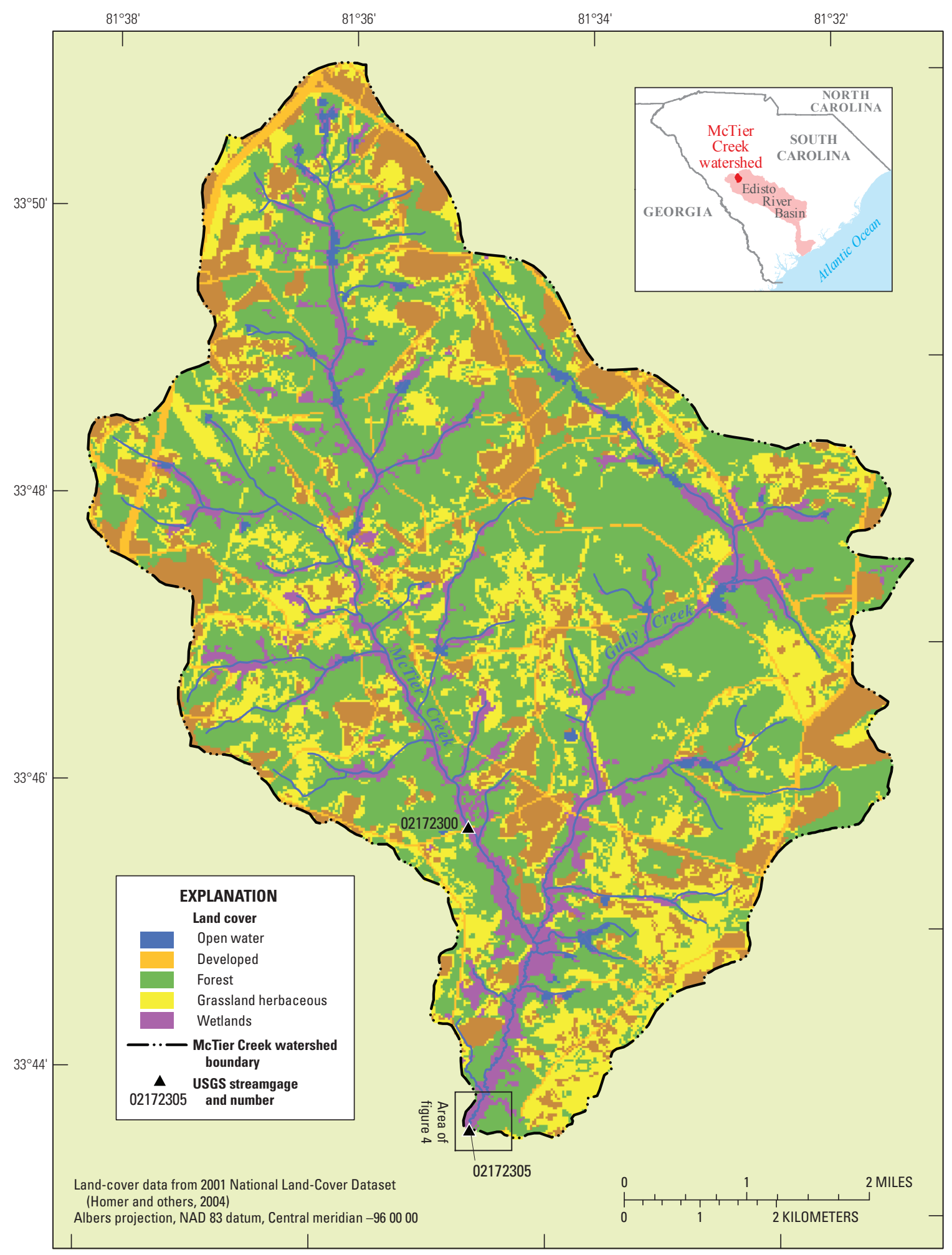

Figure 2. Land-cover map for McTier Creek watershed in South Carolina, 2001. 
Table 1. Characteristics of Fishing Brook and McTier Creek watersheds.

$\left[\mathrm{mi}^{2}\right.$, square mile; \%, percent]

\begin{tabular}{|c|c|c|}
\hline Characteristic & McTier Creek & Fishing Brook \\
\hline Drainage area & $28 \mathrm{mi}^{2}$ & $25 \mathrm{mi}^{2}$ \\
\hline Land cover (Homer and others, 2004) & $\begin{array}{l}50 \% \text { forest, } 20 \% \text { grassland/herbaceous, } \\
16 \% \text { agricultural, } 8 \% \text { wetland, } \\
5 \% \text { developed, } 1 \% \text { open water. }\end{array}$ & $\begin{array}{l}87 \% \text { forest, } 9 \% \text { wetland, } 3 \% \text { open water, } \\
1 \% \text { developed. }\end{array}$ \\
\hline Major topographic features & $\begin{array}{l}\text { Sand hills/bluffs bordering stream; probable } \\
\text { seepage controls }\end{array}$ & $\begin{array}{l}\text { Numerous hill areas, glacial till, some areas } \\
\text { of sand lenses. }\end{array}$ \\
\hline Hydrologic and ecologic features & $\begin{array}{l}\text { Continuous riparian creek border characterized } \\
\text { by extensive seeps, nonvegetated back-levee } \\
\text { pools, and vegetated back-levee pools (bogs) } \\
\text { at the base of the surrounding sand-hills } \\
\text { Extensive beaver pond wetlands in Gully Creek } \\
\text { Perennial groundwater-dominated wetlands at } \\
\text { juncture of Gully Creek and McTier Creek } \\
\text { Perennial groundwater-dominated wetland near } \\
\text { USGS streamgage } 02172305\end{array}$ & $\begin{array}{l}\text { Riparian wetlands of different hydro-ecological } \\
\text { classes, including large areas of alder- } \\
\text { dominated wetlands, large areas of ever- } \\
\text { green-dominated wetlands; some permanent- } \\
\text { ly saturated, others seasonally saturated. } \\
\text { Largest major wetland complex is County-Line } \\
\text { Flow Swamp (also called Sixmile flow), } \\
\text { considered a "Charismatic megawetland" } \\
\text { by Spada and others (not dated); primarily } \\
\text { a deciduous shrub riparian zone. }\end{array}$ \\
\hline Access & $\begin{array}{l}\text { Road access points at four locations; system } \\
\text { is not navigable }\end{array}$ & $\begin{array}{l}\text { Road access to some sites via seasonal roads- } \\
\text { Ski/snowshoe/possible snowmobile access } \\
\text { during winter; hiking during spring } \\
\text { mud season. }\end{array}$ \\
\hline
\end{tabular}

\section{Methods of Investigation}

\section{Soil Sampling}

Within each of the two watersheds, four distinct landcover compartments were identified for sampling. For the Fishing Brook watershed, the four compartments that were identified and sampled were hardwood hillslope, coniferous riparian, alder wetland, and grassy wetland. A total of 163 samples were collected at 70 separate locations in the Fishing Brook watershed (fig. 3). All samples were collected in fall 2008.

All of the McTier Creek watershed samples were collected in the vicinity of USGS streamgage 02172305 , where the surrounding sand hills slope down to the flood plain and creek. The four land-cover compartments identified and sampled in this watershed were hilltop, hillslope, riparian flood plain, and wetland. Two transects were established within each of the four land-cover compartments, and three samples were collected along each transect. For the McTier Creek watershed, a total of 81 samples were collected at 24 locations (fig. 4).

A shovel and hand auger were used to collect all soil samples. A minimum of two samples were collected and placed into sediment vials at each sampling location, with the $\mathrm{O}, \mathrm{A}$, and $\mathrm{B}$ horizons (fig. 5) being the most frequently sampled soil layers in all of the landscape compartments. In addition, at least one sampling location within each compartment was sampled across all horizons $(\mathrm{O}, \mathrm{A}, \mathrm{E}, \mathrm{B}$, and $\mathrm{C})$ in order to provide detailed geochemistry for a complete soil profile for each of the compartments. In wetland compartments soil horizons were not well developed in the highly decomposed organic matter so samples were characterized by the depths at which they were taken.

\section{Soil-Sample Analyses}

Samples were analyzed by a USGS contract laboratory for total mercury, selenium, total and carbonate carbon, and 42 other elements. These data can be used to characterize the spatial and vertical variability of mercury in soils within each compartment and can be extrapolated to the larger watershed. Results from total mercury analyses were used to select subsets of the soil samples for methylmercury analyses by the USGS Mercury Research Laboratory in Wisconsin.

O-horizon soils were air dried, milled, and split, with one portion set aside for mercury and selenium analysis and the remainder of the sample ashed at 500 degrees Celsius. The bulk of the material lost on ignition when highly organic samples are ashed is some form of carbon, with minor quantities of other elements, such as nitrogen. Thus, weight 


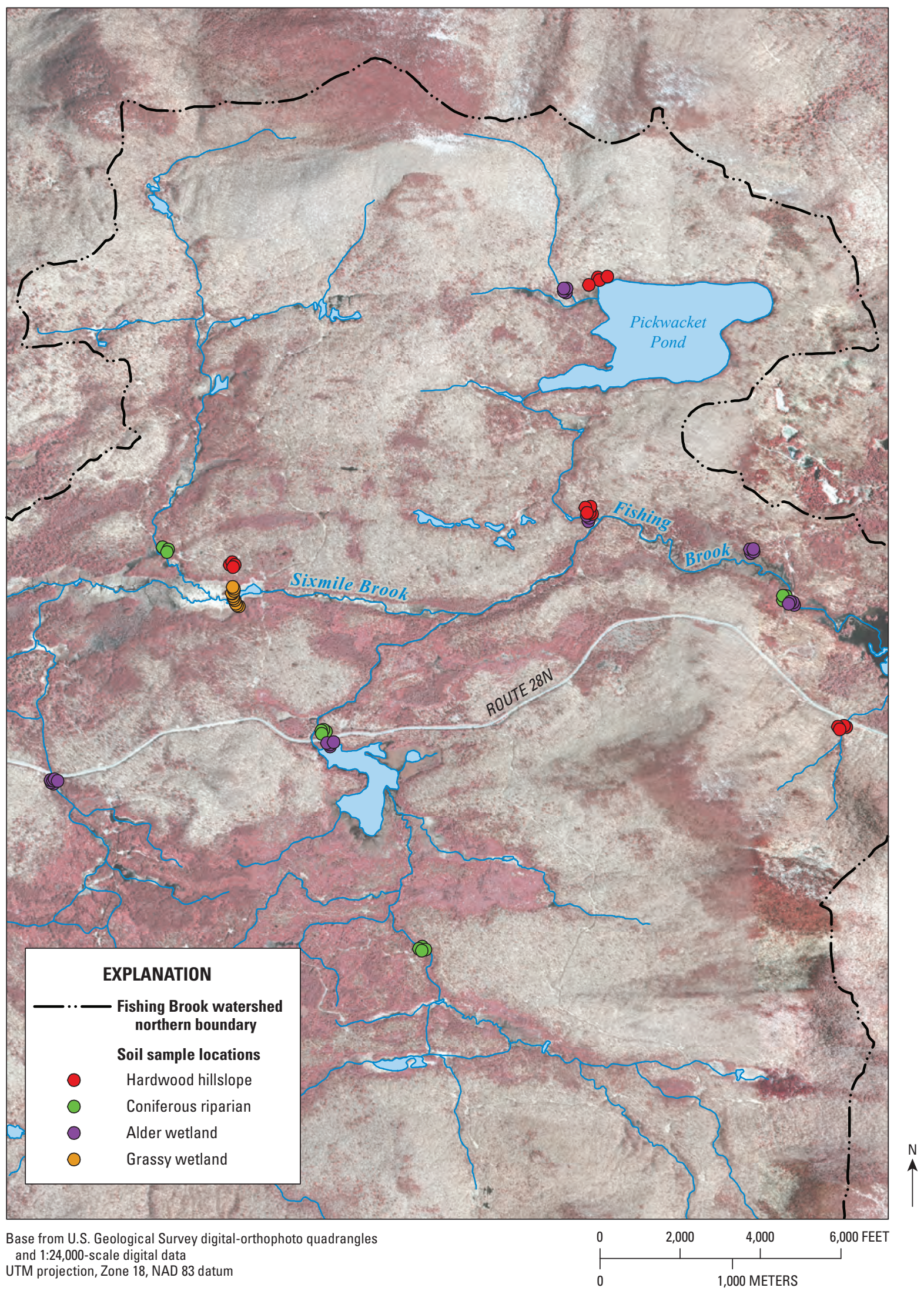

Figure 3. Soil-sample locations in the Fishing Brook watershed, New York, 2008. 


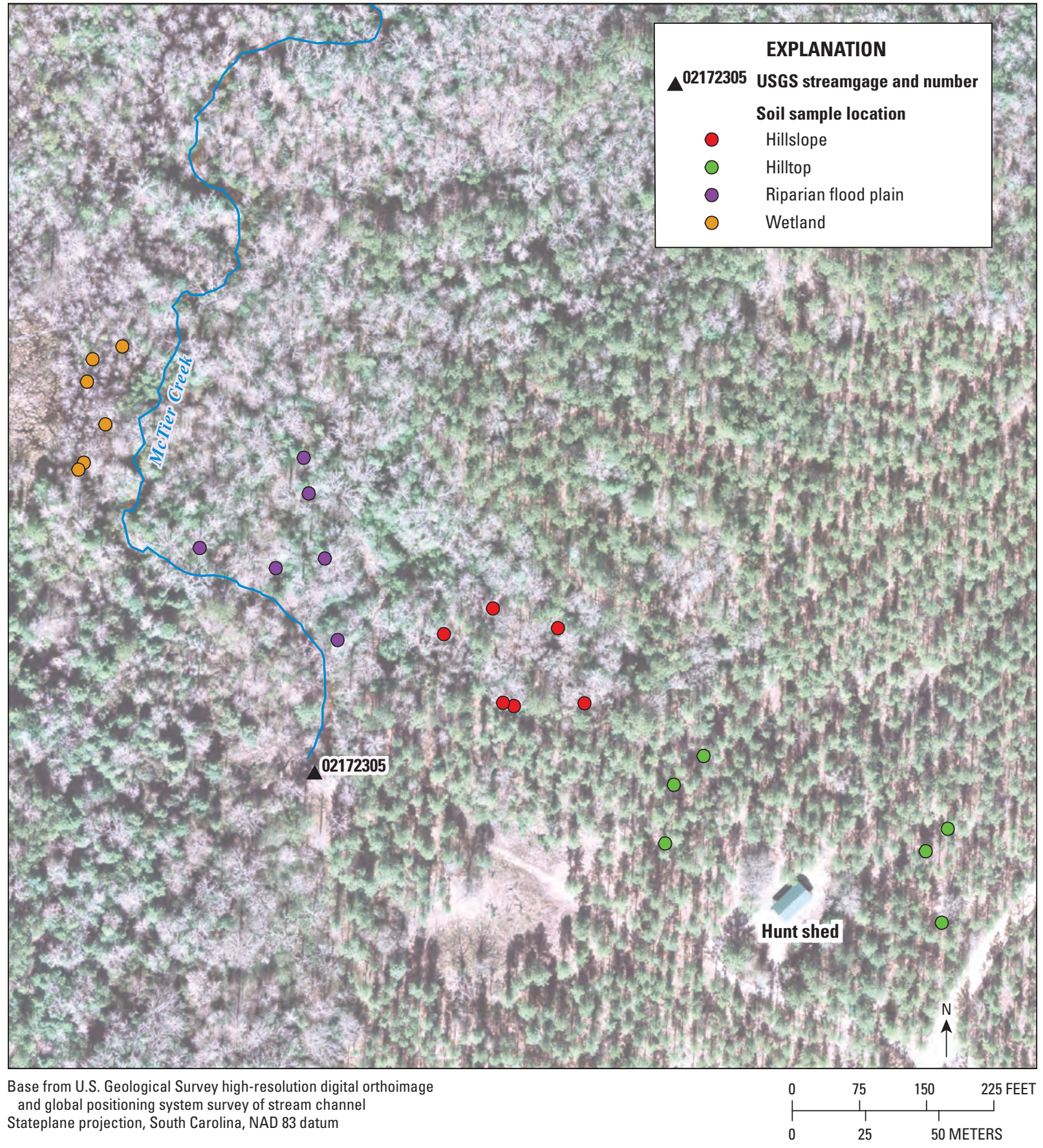

Figure 4. Soil-sample locations in the McTier Creek watershed, South Carolina, 2008. 


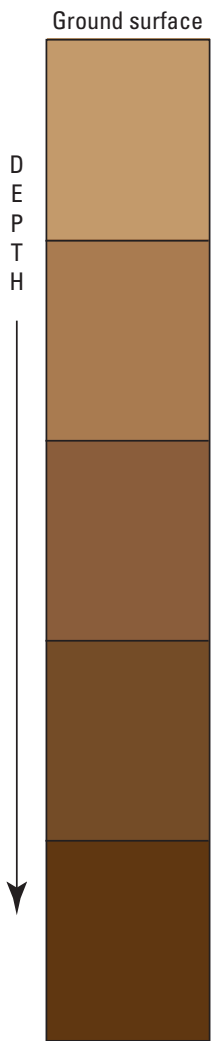

“0" Horizon—Layer dominated by organic material.

"A" Horizon-Mineral horizons that formed at the surface or below an 0 horizon that exhibit obliteration of all or much of the original rock structure and (i) are characterized by an accumulation of humified organic matter intimately mixed with the mineral fraction and not dominated by properties characteristic of $E$ or $B$ horizons; or (ii) have properties resulting from cultivation, pasturing, or similar kinds of disturbance.

"E" Horizon-Mineral horizons in which the main feature is loss of silic ate clay, iron, aluminum, or some combination of these, leaving a concentration of sand and silt particles of quartz or other resistant materials.

"B" Horizon-Horizons that formed below an $\mathrm{A}, \mathrm{E}$, or $\mathrm{O}$ horizon and are dominated by obliteration of all or much of the original rock structure and show one or more of the following: illuvial concentration of silicate clay, iron, aluminum, humus, carbonates, gypsum, or silica, alone or in combination; evidence of removal of carbonates; residual concentration of sesquioxides; coatings of sesquioxides that make the horizon conspicuously lower in value, higher in chroma, or redder in hue than overlying and underlying horizons without apparent illuviation of iron; alteration that forms silicate clay or liberates oxides or both and that forms granular, blocky, or prismatic structure if volume changes accompany changes in moisture content; or brittleness.

Horizons or layers, excluding hard bedrock, that are little affected by pedogenic processes and lack properties of $\mathrm{O}, \mathrm{A}, \mathrm{E}$, or $\mathrm{B}$ horizons. The material of $\mathrm{C}$ horizons may be either like or unlike that from which the solum presumably formed. The $\mathrm{C}$ horizon may have been modified even if there is no evidence of pedogenesis.

Notes: (1) A lowercase "a" used in conjunction with a horizon's letter designation indicates the presence of highly decomposed organic material where rubbed fiber content averages $<1 / 6$ of the volume. (2) A numeral used in conjunction with a horizon's letter designation indicates a minor shift in color or texture (with increasing depth) within that horizon and could be considered a sub-horizon of the master horizon.

Figure 5. Soil horizons sampled in the Fishing Brook watershed, New York, and the McTier Creek watershed, South Carolina, 2008 (modified from Soil Survey Division Staff, 1993). 
percent ash is a good approximation for weight percent carbon for O-horizon samples. Ashed material was submitted for analysis by a 42-element multi-acid combined inductively coupled plasma-atomic emission spectrometry and inductively coupled plasma-mass spectrometry method (ICP-AES/MS).

Quality assurance (QA) of sample analysis, including the components of standard operating procedures, instrument logs, training records, data acceptance/rejection criteria, and laboratory audits, was mainly the domain of the two laboratories. Unlike the unquantifiable QA element, the quality control (QC) element measures the accuracy and precision of the data produced by an analytical method. The accuracy and precision are established through the analysis of reference materials (RM) and sample replicates, respectively. The samples taken through the analytical process for inorganic constituents received QC checks on three separate levels. The first level of quality assurance involved QC assessment by the USGS contract laboratory. In the next level, QC was assessed by the USGS QC officer, followed by the third-level assessment by the USGS principal investigator. The USGS contract laboratory is accredited to the ISO/IEC 17025 standard, which includes both QA and QC protocols. The QC is monitored by analyzing a RM with every batch of 48 samples. The RM most often used is a syenite rock standard (SY-3) developed by the Canadian Centre for Mineral and Energy Technology (Govindaraju, 1989). Shewhart Control Charts (Taylor, 1987) are generated for the RM analyses and reviewed with every report as part of the internal quality audits. The accuracy for elements determined by ICP-AES/MS was considered acceptable if recovery was within the range of 85-115 percent at five times the lower limits of detection (LLD). The accuracy for mercury and selenium was considered acceptable if recovery was within 80-120 percent at five times the LLD.

Soil samples were air dried and sieved to $<2$ millimeters. Total carbon was determined by an automated carbon analyzer; carbonate carbon was determined as carbon dioxide by coulometric titration; organic carbon was calculated as the difference between total carbon and carbonate carbon. Mercury was analyzed by cold vapor atomic absorption (CVAAS) (lower detection limit $=0.02$ parts per million [ppm]), selenium analyzed by CVAAS (lower detection limit $=0.01 \mathrm{ppm}$ ), and 42 other elements analyzed by ICP-AES/MS (table 2). Methylmercury was analyzed using methods of DeWild and others (2004).

\section{Total Mercury, Methylmercury, and Selected Elements in Soils}

Digital files of soil geochemistry are available for soil samples collected in the Fishing Brook watershed (table 3) and the McTier Creek watershed (table 4). The data are downloadable separately and sorted by sampling site number and horizon. (These tables are available at http://pubs.usgs.gov/ $d s / 516 /$.) 
Table 2. Analytes, reporting limits, and analytical methods used for soil samples.

[wt. \%, weight percent; ppm, parts per million; ng/g, nanogram per gram; ICP-AES/MS, multi-acid combined inductively coupled plasmaatomic emission spectrometry and inductively coupled plasma-mass spectrometry; CVAAS, cold vapor atomic absorption spectrometry]

\begin{tabular}{|c|c|c|c|}
\hline Analyte & Reporting unit & Reporting limit & Analytical method \\
\hline Aluminum, $\mathrm{Al}$ & wt. $\%$ & $0.01 \%$ & ICP-AES/MS \\
\hline Antimony, $\mathrm{Sb}$ & ppm & $0.05 \mathrm{ppm}$ & ICP-AES/MS \\
\hline Arsenic, As & ppm & $1 \mathrm{ppm}$ & ICP-AES/MS \\
\hline Barium, Ba & ppm & $5 \mathrm{ppm}$ & ICP-AES/MS \\
\hline Beryllium, Be & ppm & $0.1 \mathrm{ppm}$ & ICP-AES/MS \\
\hline Bismuth, Bi & ppm & $0.04 \mathrm{ppm}$ & ICP-AES/MS \\
\hline Cadmium, $\mathrm{Cd}$ & ppm & $0.1 \mathrm{ppm}$ & ICP-AES/MS \\
\hline Calcium, $\mathrm{Ca}$ & wt. $\%$ & $0.01 \%$ & ICP-AES/MS \\
\hline Carbon dioxide, $\mathrm{CO}_{2}$ & wt. $\%$ & $0.01 \%$ & Coulometric titration \\
\hline Carbon, $\mathrm{C}$ & wt. \% & $0.01 \%$ & Automated carbon analyzer \\
\hline Carbonate carbon, $\mathrm{CO}_{3}$ & wt. $\%$ & $0.05 \%$ & Coulometric titration \\
\hline Cerium, $\mathrm{Ce}$ & ppm & $0.05 \mathrm{ppm}$ & ICP-AES/MS \\
\hline Cesium, Cs & ppm & $0.05 \mathrm{ppm}$ & ICP-AES/MS \\
\hline Chromium, $\mathrm{Cr}$ & ppm & $1 \mathrm{ppm}$ & ICP-AES/MS \\
\hline Cobalt, Co & ppm & $0.1 \mathrm{ppm}$ & ICP-AES/MS \\
\hline Copper, $\mathrm{Cu}$ & ppm & $0.5 \mathrm{ppm}$ & ICP-AES/MS \\
\hline Gallium, Ga & ppm & $0.05 \mathrm{ppm}$ & ICP-AES/MS \\
\hline Indium, In & ppm & $0.02 \mathrm{ppm}$ & ICP-AES/MS \\
\hline Iron, $\mathrm{Fe}$ & wt. \% & $0.01 \%$ & ICP-AES/MS \\
\hline Lanthanum, La & ppm & $0.5 \mathrm{ppm}$ & ICP-AES/MS \\
\hline Lead, $\mathrm{Pb}$ & ppm & $0.5 \mathrm{ppm}$ & ICP-AES/MS \\
\hline Lithium, Li & ppm & $1 \mathrm{ppm}$ & ICP-AES/MS \\
\hline Magnesium, Mg & wt. \% & $0.01 \%$ & ICP-AES/MS \\
\hline Manganese, Mn & ppm & $5 \mathrm{ppm}$ & ICP-AES/MS \\
\hline Mercury, THg & ppm & $0.02 \mathrm{ppm}$ & CVAAS \\
\hline Methylmercury, MeHg & $\mathrm{ng} / \mathrm{g}$ & $0.08 \mathrm{ng} / \mathrm{g}$ & DeWild and others, 2004 \\
\hline Molybdenum, Mo & ppm & $0.05 \mathrm{ppm}$ & ICP-AES/MS \\
\hline Nickel, Ni & ppm & $0.5 \mathrm{ppm}$ & ICP-AES/MS \\
\hline Niobium, $\mathrm{Nb}$ & ppm & $0.1 \mathrm{ppm}$ & ICP-AES/MS \\
\hline Organic carbon, TOC & wt. $\%$ & $0.05 \%$ & Computed from $\mathrm{C}$ and $\mathrm{CO}_{3}$ \\
\hline Phosphorus, $\mathrm{P}$ & ppm & $50 \mathrm{ppm}$ & ICP-AES/MS \\
\hline Potassium, K & wt. $\%$ & $0.01 \%$ & ICP-AES/MS \\
\hline Rubidium, $\mathrm{Rb}$ & ppm & $0.2 \mathrm{ppm}$ & ICP-AES/MS \\
\hline Scandium, Sc & ppm & $0.1 \mathrm{ppm}$ & ICP-AES/MS \\
\hline Selenium, Se & ppm & $0.01 \mathrm{ppm}$ & CVAAS \\
\hline Silver, Ag & ppm & $1 \mathrm{ppm}$ & ICP-AES/MS \\
\hline Sodium, $\mathrm{Na}$ & wt. $\%$ & $0.01 \%$ & ICP-AES/MS \\
\hline Strontium, Sr & $\mathrm{ppm}$ & $0.5 \mathrm{ppm}$ & ICP-AES/MS \\
\hline Sulfur, S & wt. \% & $0.01 \%$ & ICP-AES/MS \\
\hline Tellurium, Te & ppm & $0.1 \mathrm{ppm}$ & ICP-AES/MS \\
\hline Thallium, Tl & ppm & $0.1 \mathrm{ppm}$ & ICP-AES/MS \\
\hline Thorium, Th & ppm & $0.2 \mathrm{ppm}$ & ICP-AES/MS \\
\hline Tin, Sn & ppm & $0.1 \mathrm{ppm}$ & ICP-AES/MS \\
\hline Titanium, Ti & wt. $\%$ & $0.01 \%$ & ICP-AES/MS \\
\hline Tungsten, W & ppm & $0.1 \mathrm{ppm}$ & ICP-AES/MS \\
\hline Uranium, U & ppm & $0.1 \mathrm{ppm}$ & ICP-AES/MS \\
\hline Vanadium, $\mathrm{V}$ & ppm & $1 \mathrm{ppm}$ & ICP-AES/MS \\
\hline Yttrium, Y & ppm & $0.1 \mathrm{ppm}$ & ICP-AES/MS \\
\hline Zinc, $\mathrm{Zn}$ & $\mathrm{ppm}$ & $1 \mathrm{ppm}$ & ICP-AES/MS \\
\hline
\end{tabular}




\section{References Cited}

DeWild, J.F., Olund, S.D., Olson, M.L., Tate, M.T., 2004, Methods for the preparation and analysis of solids and suspended solids for methylmercury: U.S. Geological Survey Techniques and Methods Report 5-A7, 21 p., accessed at http://pubs.usgs.gov/tm/2005/tm5A7/.

Govindaraju, K., ed., 1989, 1989 compilation of working values and sample description for 272 geostandards: Geostandards and Geoanalytical Research, v. 13, no. s1, p. 1-113.

Grigal, D.F., 2002, Inputs and outputs of mercury from terrestrial watersheds-A review: Environmental Review, v. 10 , no. 1, p. $1-39$.

Homer, Collin, Huang, Chengquan, Yang, Limin, Wylie, Bruce, and Coan, Michael, 2004, Development of a 2001 National Land-Cover Database for the United States: Photogrammetric Engineering \& Remote Sensing, v. 70 , no. 7 , p. $829-840$.

Krabbenhoft, D.P., and Babiarz, C.L., 1992, The role of groundwater transport in aquatic mercury cycling: Water Resources Research, v. 28, no. 12, p. 3119-3128.

Krabbenhoft, D.P., Branfireun, B.A., Heyes, A., 2005, Biogeochemical cycles affecting the speciation, fate, and transport of mercury in the environment, in Parsons, M.B., and Percival, J.B., eds., Mercury-Sources, measurements, cycles, and effects: Mineralogical Association of Canada, Short Course Series, v. 34, p. 139-156.
Lorey, Peter, and Driscoll, C.T., 1999, Historical trends of mercury deposition in Adirondack lakes: Environmental Science \& Technology, v. 33, no. 5, p. 718-722.

Soil Survey Division Staff, 1993, Soil survey manual agricultural handbook no. 18, chapter 3: Soil Conservation Service, U.S. Department of Agriculture Handbook 18, p. 46-59.

Spada, D.M., Halasz, S.S., and Karasin, L.N., [not dated], Database of Charismatic Wetlands in the Adirondack Park: New York State Adirondack Park Agency, 34 slides, accessed June 29, 2010, at http://www.apa.state.ny.us/ Research/Megawetlands/megawtll.html.

Taylor, J.K., 1987, Quality assurance of chemical measurements: Taylor \& Francis, Inc., p. 129-146.

U.S. Environmental Protection Agency, 2009, 2008 Biennial national listing of fish advisories: U.S. Environmental Protection Agency, Office of Science and Technology, EPA-823-F-09-007, 7 p., accessed at http://www.epa.gov/ fishadvisories.

U.S. Environmental Protection Agency, 2010, National summary of impaired waters and TMDL information: U.S. Environmental Protection Agency, accessed at http://iaspub.epa.gov/waters10/attains_nation_ cy.control?p_report_type $=T$ Heauses_303d. 
Manuscript approved for publication, April 27, 2010

Edited by John M. Watson

Layout by Caryl J. Wipperfurth

For more information concerning the research in this report, contact Laurel Woodruff U.S. Geological Survey Eastern Minerals and Environmental Science Center 2280 Woodale Drive

Mounds View, MN 55112

(763) 783-3291

woodruff@usgs.gov 


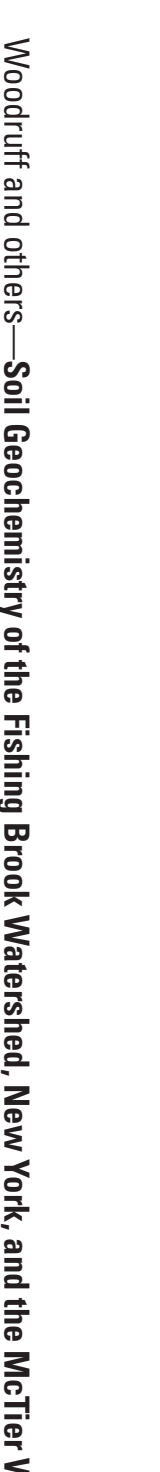

